\title{
The Role of the State in Upstream Oil and Gas Gross Split Contracts
}

\author{
Muhammad Fajri \\ \{mfajri85@gmail.com\} \\ Faculty of Law, Airlangga University
}

\begin{abstract}
The enactment of the Republic of Indonesia Minister of Energy and Mineral Resources Regulation Number 08 of 2017 regarding Gross Split Production Sharing Contracts marks a new era for Indonesia's Upstream Oil and Gas Industry. Gross Split was introduced as the government's answer to the dissatisfaction with the Cost Recovery scheme that has been going on for decades. Without making changes to Law No. 22 of 2001 concerning Oil and Gas, the Government considered it necessary to immediately issue regulations related to the Gross Split scheme in order to increase state revenues in the upstream oil and gas sector. Gross Split contracts also offer bureaucratic cuts in investment procedures expected to attract investors. This research aimed to analyse the legal aspect related to Gross Split regulation and to determine the extent of the government's role in implementing control and supervision of contractor activities in the Gross Split Scheme.
\end{abstract}

Keywords: Gross Split, Production Sharing Contract, Upstream Activities

\section{Introduction}

Indonesia is known as a country blessed with abundant natural resources. The ultimate gift of God is essentially an important capital in the implementation of national development. The most important natural resource commodity that we have today is oil and gas. The status as one of the non-renewable natural resources makes upstream oil and gas business activities play a strategic role in national development. Oil and gas is known as one of the largest sources of state revenue highly relied upon to be the main catalyst in implementing development in order to realize the welfare of the Indonesian people. Hence, it is undeniable that oil and gas is a strategic commodity that plays an important role in the supply of industrial raw materials while fulfilling domestic energy needs and the country's biggest foreign exchange earner. Therefore, the management should be carried out as optimal as possible so that it can be utilized for the greatest prosperity and welfare of the people [1].

The 1945 Constitution has outlined that natural resources are controlled by the state and used as much as possible for the prosperity of the people. That's why, the monopoly of regulation, organization, use, supply and maintenance of natural resources and regulation of legal relations rests with the state. The interpretation of sentences controlled by the state is not always in the form of ownership but primarily in the form of the ability to exercise control and regulation and provide an influence so that the company adheres to the principle of the interests of the majority of the people and the greatest prosperity of the people [2]. 
The provisions contained in article 33 of the 1945 Constitution constitute moral and cultural messages in the constitution of the Republic of Indonesia in the field of economy. This article not only provides guidance on the composition of the economy and the authority of the state to regulate economic activities but also reflects the ideal, a belief that is held firmly and fought consistently by government leaders.

As described in Article 33 paragraph (2) of the 1945 Constitution: Significant production branches to the state that control the livelihood of many people are dominated by the state. Furthermore, paragraph (3) of the article states: Earth and water and the natural wealth contained in it are controlled by the state and used for the greatest prosperity of the people.

As a form of follow up on the implementation of ideals of the founding father, Law No. 22 of 2001 concerning Oil and Gas was born, which divided upstream oil and gas activities into two categories of activities, namely Exploration: The activity aimed at obtaining information about geological conditions to find and obtain estimates of oil and gas reserves in the specified working area. (Article 1 number 8 of Law 22/2001) and Exploitation: A series of activities aimed at producing oil and gas from the specified working area, which consists of drilling and completion of wells, construction of means of transportation, storage and processing for the separation and refining of oil and gas in the field and other activities that support it. (Article 1 number 9 of Law 22/2001)

Various forms of cooperation have coloured the history of managing upstream oil and gas in the country. For decades, the profit sharing contract has been carried out with a cost recovery scheme that has been known since the regime of Law Number 44 Prp. 1960 concerning Oil and Gas Mining, and Law Number 8 of 1971 concerning the State Oil and Gas Mining Company. Even though it is widely applied in various oil and gas producing countries in the world, the implementation of production sharing contract schemes in Indonesia in practice has received a lot of criticism such as statistics on the time discovery of reserves and oil and gas production that are too long, long bureaucracy in the implementation of investment activities and indications on the inefficiency in issuing operational costs that burden state finances.

The decision of the Government of the Republic of Indonesia through the Minister of Energy and Mineral Resources issuing Minister of Energy and Mineral Resources Regulation No. 8 of 2017 concerning the policy of replacing Production Sharing Contract (PSC) Cost Recovery into PSC Gross Split scheme is a new milestone in the upstream oil and gas Industry in Indonesia. This policy is motivated by the Non-Tax State Revenues (PNBP) of the oil and gas industry, which the government feels to continue to decline significantly. The Indonesian government actually continues to innovate in seeking to improve the investment climate and accelerate the execution of the development of exploration and exploitation activities in a work area. This can be seen from government policies that continue to modify regulations according to national development needs, including the improvement of Minister of Energy and Mineral Resources Regulation No. 8 of 2017 itself with several article were revised in Minister of Energy and Mineral Resources Regulation No. 52 of 2017, the purpose behind it is the government's desire to stimulate investors through incentives when developing the Plan of Development (POD) oil and gas II which has not been accommodated in previous regulations.

Many debates between practitioners and legal experts regarding this government policy, invite some views whether the change in concept of contracts with investors will be proven effective and potent in improving the investment climate in the upstream oil and gas sector that is capital intensive, has advanced technology, high risk and high uncertainty of return of investment held. Through this breakthrough, the government expects investor partners to be encouraged to be more competitive and make maximum planning terms of both technology 
determination and calculation of all risk factors. PSC Contractors are encouraged to more efficiently obtain cost-effective, investment rate of return and maximum profit.

The main control remains in the hands of the government even though the PSC Contractors are given full freedom in the management of a work area. Conceptually the gross split scheme aims to cut the chain of bureaucracy that has been a complaint of investors. The government expects that gross split will encourage contractors and supporting industries to be more efficient so that exploration and exploitation efforts carried out will be faster or timely, on budget, and achieve performance targets in line with the increase in state revenues.

The objectives of this research were to determine the legal rules of the gross split production sharing contract in supporting the improvement of the investment climate in upstream oil and gas activities and to analyse the role of the state in controlling and supervising the activities of gross split contractors.

\section{Research Method}

This research was conducted using normative legal research. Legal Research is research focused on examining the application of rules or norms in positive law [3]. According to Peter Mahmud Marzuki, "Normative legal research is prescriptive research using coherence between legal norms, legal principles, and legal doctrine, in order to answer the legal issues being faced" [4].

This research is based on legal norms in laws and regulations related to the legal aspects of the gross split profit sharing contract which relies on analysing legal issues by drawing on legal principles in managing upstream oil and gas activities and synchronizing laws and regulations related to upstream oil and gas activities that apply. The problem approach method used in the preparation of this research is the statute approach and the conceptual approach. To solve legal issues in this legal journal, an analysis of research sources was carried out, including primary and secondary legal materials.

\section{Discussion}

The upstream oil and gas industry is a business activity that is capital intensive and full of risks. It is not uncommon for many investors to lose money after having a big investment in exploration and exploitation drillings. The risk has been recognized by the government through a policy of offering work areas to prospective partners or investors who have large capitals. This way was chosen by the government because it would protect public interests by not being burdened by the State Expenditures Budget (APBN) if implemented alone.

The petroleum world calls the investor as the PSC Contractors. based on the Regulation of the Minister of Energy and Mineral Resources No. 48 of 2017 concerning Business Supervision in the Energy and Mineral Resources Sector article 1 number 1, it has been described that: $A$ Cooperation Contract Contractor (PSC), hereinafter referred to as a Contractor, is a business entity or permanent establishment that carries out exploration and exploitation in a work area based on a cooperation contract with a special work unit implementing upstream oil and gas business activities.

The mechanism for managing upstream oil and gas in Indonesia begins with the offering of work areas carried out by the Ministry of Energy and Mineral Resources, after obtaining the 
winner of the working area auction, according to the government mandate through Presidential Regulation No. 9 of 2013 concerning the Management of Upstream Oil and Gas Activities, SKK Migas as the special work unit that manages upstream oil and gas activities is appointed as the party representing the government in the signing of the Cooperation Contract with the oil and gas investors.

The definition related to cooperation contracts is contained in Law Number 22 of 2001 in article 1 number 19: Cooperation Contracts are Production Sharing Contracts or other forms of cooperation in Exploration and Exploitation activities that are more beneficial to the State and the results are used for the greatest prosperity of the people.

Further elaboration of the provisions of the cooperation contract is contained in Government Regulation Number 35 of 2004 concerning Upstream Oil and Gas Business Activities which was last revised by Government Regulation Number 55 of 2009 concerning the Second Amendment to Government Regulation No. 35 of 2004 concerning Natural Oil and Gas Upstream Business Activities. The regulation literally defines two forms of contracts that exist in Indonesia before gross split schemes are formed, including: Production Sharing Contracts are a form of cooperation contract in exploration and exploitation activities based on the principle of distribution of production. (Article 1 number 4 Government Regulation Number 35 of 2004). Service Contract is a form of cooperation contract for the implementation of oil and gas exploitation based on the principle of providing compensation for the production produced. (Article 1 number 5 Government Regulation Number 35 of 2004).

Law No. 22 of 2001 actually opens the door for other contract forms other than conventional PSC systems. The phrase "Production Sharing Contracts or other forms of cooperation" means the possibility of adapting or modifying the form of a new scheme in the management of exploration and exploitation activities while still using the principle "More beneficial to the State and the results are used for the greatest prosperity of the people". It is this grammatical interpretation that drives the government to form a new format that is felt to be in line with the development of the investment climate in the upstream oil and gas sector in Indonesia.

The Regulation of the Minister of Energy and Mineral Resources No. 08 of 2017 in Article 1 number 7 has given interpretation of Gross Split Production Sharing Contracts as follows: "Gross Split Production Sharing Contract is a Production Sharing Contract in Upstream Oil and Gas Business activities based on the principle of Gross production sharing without a mechanism for returning operating costs".

The fundamental difference between the Gross Split and the Cost Recovery is related to whether or not there is a replacement for the operating costs of the contractor. Cost Recovery is the cost paid by the Government to contractors as a replacement for production and investment costs during the exploration, exploitation and development of oil and gas blocks being worked on in a state territory. The percentage of profit sharing of the oil and gas production result from the parties involved in the profit sharing contract between the Government and the PSC Contractors of the Cost Recovery system is $85 \%$ for the state and $15 \%$ for the psc contractors for Natural Oil, and for Natural Gas about $70 \%$ for the state and $30 \%$ for the psc contractors. 


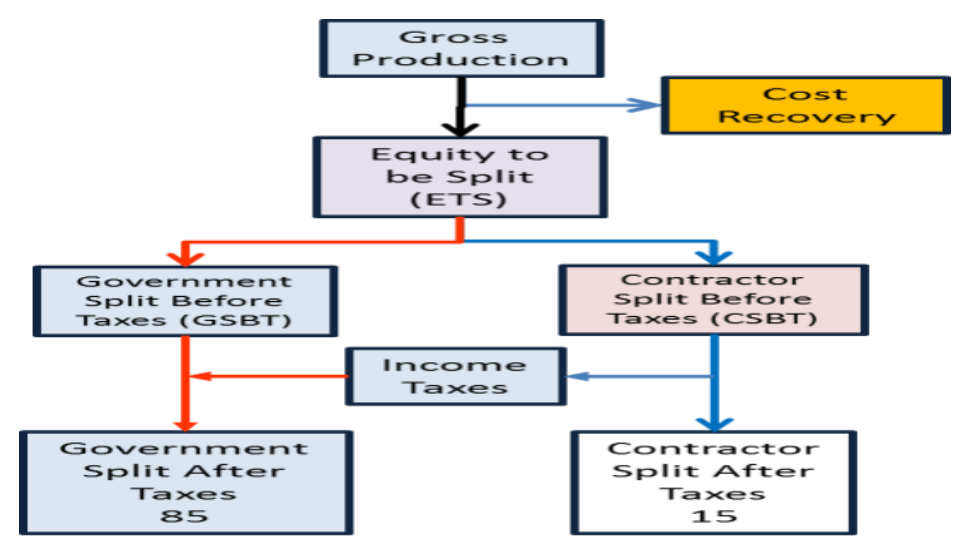

Fig. 1. Cost Recovery Scheme

In a Cost Recovery PSCs, the State and Contractors are equally involved and jointly responsible for funding and business risks. Micro management applied to the PSC scheme that is not in accordance with the provisions of making investment climate in the Cost Recovery PSC system is considered to be inadequate. Then, the cost recovery concept into the APBN has attracted sharp criticism from investors because cost recovery funds are actually not state money. This problem is tried to be solved through gross split which sets out in the beginning that the contract uses a base split mechanism that can be adjusted based on variable and progressive components, with the calculation as stipulated in article 5 Minister of Energy and Mineral Resources Regulation No. 8 of 2017 namely: Natural Oil (57\% is for the state and $43 \%$ for the contractor) and Natural Gas (52\% is for the state and $48 \%$ for the contractor).

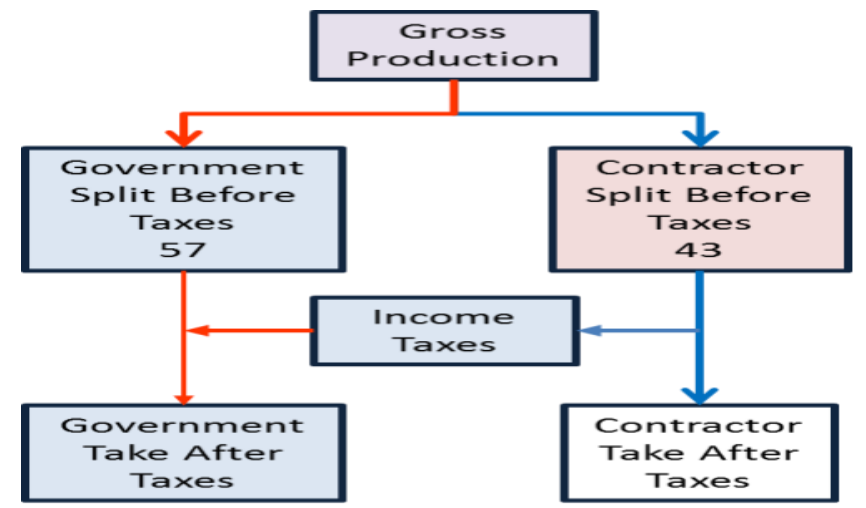

Fig. 2. Gross Split Scheme

In addition by upon scheme, state revenues becomes more certain because determined at the beginning of the activities and becomes more varied since it is not only include the formulation of state split, but also added by bonus and contractors income tax.

The government has conveyed the purpose of formulating the gross split format, which in essence is to increase the acceleration of the discovery of reserves and production of oil and gas in Indonesia which was previously felt to be ineffective. The objectives to be achieved by the government include to encourage: more effective and fast exploration and exploitation efforts, oil and gas contractors and oil and gas Supporting Industries to be more efficient so 
that they are more capable of facing oil price fluctuations from time to time, the business process of upstream oil and gas contractors and SKK Migas to be simpler and accountable, makes current bureaucratic procurement system and debates decrease, to encourage the PSCs to manage their operating and investment costs by relying on the corporate financial system rather than the state financial system.

The arrangements made by the Minister of Energy and Mineral Resources on the form and content of gross split profit sharing contracts are intended as a form of government anticipation in protecting the interests of the state and national economy. Based on Minister of Energy and Mineral Resources Regulation No. 8 of 2017 Article 3, Gross Split PSC must contain at least main conditions including: state revenues, working area and return, obligation to disbursement of funds, transfer of ownership of production of oil and gas, time period and condition of contract extension, dispute resolution, obligation to supply natural oil and/or gas for domestic needs, end of contract, obligations after mining operations, work safety and health, management of the environment, transfer of rights and obligations, reporting required, field development plan, prioritizing the use of Indonesian workers, prioritizing the use of domestic goods and services, development of the surrounding community and guarantee of the rights of indigenous peoples.

Efforts to increase investment in upstream oil and gas are seen in the facilities provided by the state to contractors in the Minister of Energy and Mineral Resources Regulation No. 8 of 2017 is the enactment of additional components that act as incentives in the distribution of results, contractors get an "additional \% split" from base split, depending on the components as follows:

a. Variable components, such as: block status, field location (onshore or offshore, remote), reservoir depth, supported infrastructure, reservoir conditions, CO2 content, H2S content, specific gravity (API), local Content (TKDN), production phase.

b. Progressive components such as natural oil prices, gas prices and the cumulative amount of oil and gas production.

Oil and gas as a strategic non-renewable natural resource contained in the Indonesian Mining Law Area constitutes national wealth controlled by the State. Law No. 22 of 2001 has stipulated the concept of control and exploitation as stated in Article 4: (1) Oil and Gas as a non-renewable strategic natural resource contained in the Indonesian Mining jurisdiction constitutes national wealth controlled by the State. (2) State control as referred to in paragraph 1 shall be held by the Government as the holder of Mining Authorization.

The Indonesian government in managing natural resources must be smart in choosing the most profitable business patterns and provide optimal state revenues. Ideally the business patterns chosen by a sate should be in harmony with the natural resource management regime used. As an illustration, if the government implements a private property concept, the most suitable business pattern or scheme is the concession system. Whereas if the government chooses the state property concept, the business pattern used is the contract system, both the profit sharing contract and the service contract. From the legal principle, it can be concluded that the concept of the gross split production sharing contract as regulated by Minister of Energy and Mineral Resources Number 8 of 2017 and the amendment is not in conflict with the elements contained in the superior hierarchy of laws and regulations on Law No. 22 of 2001.

The gross split production Sharing Contract has fulfilled the material/substantive requirements stipulated in Article 6 of Law Number 22 of 2001, which is described again in article 2 of Minister of Energy and Mineral Resources Regulation No. 8 of 2017 concerning the terms of the cooperation contract: ownership of natural resources remains in the hands of the 
government until the point of delivery, operational management control is at SKK Migas,all the capital and risk are borne by the Contractor ${ }^{1}$.

The role of the state in the implementation of upstream oil and gas business activities is seen in its position to carry out guidance, supervision and control. The guidance is carried out in the context of organizing government affairs and establishing policies carried out through the Ministry of Energy and Mineral Resources (ESDM). Meanwhile, the control and supervision functions carried out by SKK Migas are intended to safeguard the compliance of PSC contractors to the provisions of cooperation contracts. This complex pattern of relations arises because the role of upstream oil and gas is very strategic for the State so that it is deemed necessary to distribute the authority to the two agencies. Article 23 of Minister of Energy and Mineral Resources Regulation No. 8 of 2017 concerning Gross Split Production Sharing Contracts has determined that:

(1) SKK Migas implements control and supervision of the implementation of gross split profit sharing contracts.

(2) Control as referred to in paragraph 1 is limited to the formulation of policies on work plans and budgets proposed by contractors as referred to in article 15 paragraph 1.

(3) Supervision as referred to in paragraph 1 is carried out on the realization of the main operational activities of the contractor covering exploration and exploitation activities in accordance with the work plan agreement.

Based on the provisions of the article above, the role of the state to carry out management and supervision can be constructed as follows:

\subsection{Control}

Regarding the position of the State in the implementation of cooperation contracts, in practice the State certainly has limitations in carrying out business transactions. Besides, involving the state directly in business ties certainly creates unlimited legal accountability. This conception has been anticipated by Law 22 of 2001 considering the need for the establishment of a legal entity that has its own assets and organs, the purpose of which is that the business accountability is limited to company assets [5].

The position of the state as the ruler of natural resources as well as the policy controller in implementing contracts is also implied by the conception of ownership of operating goods, equipment and land, as described in Minister of Energy and Mineral Resources Regulation No. 8 of 2017 in Article 21: All goods and equipment directly used in upstream oil and gas business activities purchased by contractors become the property/wealth of the State whose guidance is carried out by the government and managed by SKK Migas, also in Article 22 (1): The land whose acquisition process has been completed by the contractor belongs to the State and is managed by SKK Migas, except for leased land.

The state will immediately become the owner of the goods and can record them in its wealth the purchase of the operating goods, equipment and land carried out by the contractor. This

${ }^{1}$ Prahoro Nurtjahyo, 2017, Menjawab Keraguan Terhadap Gross Split: Tanggapan atas Opini Dr Madjedi Hasan "Potensi Permasalahan dalam Gross Split" (Response to Doubts Against Gross Split: Responses to Dr. Madjedi Hasan's Opinion "Potential Problems in the Gross Split"), https://www.esdm.go.id/assets/media/content/content-menjawab-keraguan-terhadap-gross-splittanggapan-atas-opini-dr-madjedi-hasan-potensi-permasalahan-dalam-gross-split.pdf (accessed on 10 February 2019) 
causes a debate because in the planning the contractor no longer requests the approval of SKK Migas. Likewise in terms of the budget and time frame for the procurement process, the realization of the procurement of goods and services no longer involves the participation of SKK Migas. PSC contractor is welcome to form procurement methods or instructions carried out independently or internally without reference to implementation provisions or work guidelines issued by SKK Migas, but is limited by the corridor of protection of state interests, as described in Article 18 of Energy and Mineral Resources that the contractors must prioritize the use of Indonesian workers, the use of goods, services, technology and engineering and design capabilities in the country and Procurement of goods and services is carried out by contractors independently.

Basically, Minister of Energy and Mineral Resources Regulation No. 8 of 2017 provides greater state influence which can be seen from the determination of work areas, determination of production and lifting capacity and distribution of results determined by the state.

\subsection{Supervision}

The operational management in the Gross Split Production Sharing Contract is in SKK Migas, as stated in the provisions of article 15 of the Minister of Energy and Mineral Resources Regulation No. 8 of 2017 that the PSC contractors is required to prepare and submit a work plan and budget to SKK Migas.

Although cost recovery is not applied on fees, the PSC contractor is still required to submit a Work Plan and Budget to SKK Migas which means the contractor is not fully independent in controlling costs. The obligation to prioritize domestic components has also reduced the independence of contractors in controlling costs. It can be concluded that SKK Migas is still implementing control and supervision of the implementation of gross split production sharing contracts even though it is limited to the formulation of policies on work plans submitted by contractors. Regarding this matter, the state is no longer burdened with the realization of the budget as happened in the cost recovery system because budget approval is limited to supporting data in evaluating work plans. Supervision is more focused on the technical evaluation matters including reviewing drilling activities, plan of development and contractors performance in environmental aspects, increasing national worker capacity and prioritizing the use of domestic goods.

\section{Conclusion}

The gross split business scheme shows that the upstream oil and gas industry is moving dynamically. The Special Work Unit for Implementing Upstream Oil and Gas Business Activities (SKK Migas) as an extension of the government in the business of upstream oil and gas industry in the state management function still has a role even though the tasks in calculating and controlling cost recovery no longer exist. The contractor's work program plan is still requested for approval from SKK Migas as a form of control and supervision of the State.

In addition to ensuring the role of the State as the holder of mining rights, the gross split scheme also offers incentives to improve the investment climate. As explained in the Minister 
of Energy and Mineral Resources Regulation No. 8 of 2017 concerning Gross Split Production Sharing Contracts and Amendments, investors are given assurance of the base split portion determined at the beginning of the contract. This is coupled with incentives provided by the Government in the form of Variable and Progressive Components.

\section{References}

[1] Soenarto, Peluang Bagi Penyelesaian Konflik Agraria Di Sub Sektor 1 Pertambangan Umum, Jurnal Analisis Sosial Vol. 9, Number 1, April 2004.

[2] Manan, Bagir, Pertumbuhan dan Perkembangan Konstitusi Suatu Negara (Growth and Development of the Constitution of a Country), Mandar Maju: Jakarta, 1995.

[3] Ibrahim, Johny, Teori dan Metodologi Penelitian Hukum Normatif (Theory and Methodology of Normative Legal Research), Bayumedia Publishing: Malang, 2006.

[4] Mahmud, Peter, Penelitian Hukum (Legal Research), Jakarta: Kencana, 2011.

[5] Utomo, Lalang T., Achmad Busro, Ery Agus Priyono, Aspek Hukum Penerapan Asas Kekuatan Mengikat dalam Kontrak Bagi Hasil Minyak dan Gas Bumi di Indonesia, Diponegoro Law Journal Vol. 5, Number 4, Year 2016. 